\title{
From Carlyle's Hero to Conrad's Depraved: Hermeneutics of Morbidity in Heart of Darkness
}

\author{
Eduardo Valls Oyarzun \\ Complutense University, Madrid, Spain
}

The author of this paper lays out a system of hermeneutics based on the idea of morbidity aimed at checking the commitment (or the lack thereof) of individual subjects to Victorian ethics. The system stems from Thomas Carlyle's political agenda based on his concept of "hero worship". The system is then deployed in order to probe into the purported morbidity of Joseph Conrad's Heart of Darkness. According to the author of this paper, the character of Marlow represents a curious mixture of the heroic archetype proposed by Carlyle, combined with new critical standpoints from other philosophical programmes (specifically Nietzsche's) proposed at the end of the nineteenth century. Firstly, the author of this paper tackles the prototype of the hero (a sort of medium between reality and Divine Truth) Thomas Carlyle posited in his On Heroes, Hero-Worship, and the Heroic in History (1841). The author of this paper then describes how Marlow shares some of the hero's features (most notably social responsibility and work ethic), but fails to embody the main trait of Carlyle's "great men", namely, their ability to recognize Divine Truth. Indeed, rather than asserting the existence of the Truth, Marlow's narrative reveals the existence of multiple truths, thus creating a sort of politically morbid revision of Carlyle's formula.

\section{Keywords}

Hero; morbidity; responsibility; Joseph Conrad; Thomas Carlyle; Friedrich Nietzsche; Victorian critique

In the Author's Note to Lord fim, Joseph Conrad notably commented on one specific response the novel elicited:

A friend of mine returning from Italy had talked with a lady there who did not like the book. I regretted that, of course, but what surprised me 
was the ground of her dislike. "You know", she said, "it is all so morbid." The pronouncement gave me food for an hour's anxious thought. Finally I arrived at the conclusion that, making due allowances for the subject itself being rather foreign to women's normal sensibilities, the lady could not have been an Italian. I wonder whether she was European at all? In any case, no Latin temperament would have perceived anything morbid in the acute consciousness of lost honour. (Conrad 2000,6)

Assuming the lady was actually Italian, critics must face the possibility that Conrad might not have touched upon the truth, as well as that, after all, the Italian temperament can actually perceive something morbid in the "acute consciousness of lost honour". It is either that, or the more likely hypothesis that both Conrad (through Conrad's friend) and the Italian lady were discussing two completely different things: communal Idealism on the one hand, and modern individualism on the other. Conrad indeed claims honour lies at the core of the novel, and surely Idealism pertains to the idea of honour, which in turn befits Jim's character perfectly well (Hillis Miller 30). But the "acute consciousness of lost honour" (Conrad 2000,6) that accounts for the character of Jim features an individualistic trait that might create friction with the traditional ideal of honour. Thus, the key to understanding this riddle might not be in the idea of honour, but rather in the way the ideological substratum the idea of honour entails unfolds in the novel.

Heart of Darkness (1899) had already set a narrative standard to deal with this issue. Specifically, the popular novella lets the modern ideological substrata unfold in a "morbid" way, that is, through a carefully balanced process whereby modern subjectivity debunks Victorian Idealism. The ultimate goal of this paper is to outline the foundations of a hermeneutical system based on the idea of the "morbid" in order to understand this process precisely. Arguably, Marlow's development, as a character/narrator, coheres into a curious type of heroism (à la Thomas Carlyle, 1795-1881) laced with the new critical standpoint other philosophical programmes (most notably Nietzsche's) proposed at the end of the nineteenth century. Firstly, I will present the figure of the hero (a sort of conduit between reality and the Divine Truth) Thomas Carlyle posited in his essay On Heroes, Hero-Worship, and the Heroic in History (1841) in order to understand the Victorian ideological framework at the core of the archetype. Then I will probe into the ways in which Marlow somewhat fits the prototype of the Carlylean hero. He does so, to some extent; but ultimately fails to embody the main trait of Carlyle's "great men", namely, their ability 
to recognize the Divine Truth. For rather than asserting the existence of "the Truth", Marlow's narrative reveals the existence of multiple, individual layers of truths, thus creating a seemingly postmodern sort of perspectivism that could explain the morbid feeling Victorian readers like the Italian lady experienced when dealing with Conrad. Even though the influence of Carlyle in Conrad has already been discussed (Watt 149-151; Ruppel 13), mostly regarding the concepts of "duty" and "truth", a subversive critique of Carlyle's heroic pattern Marlow's narrative deploys has never been delved into. The present outline of morbidity as a hermeneutical process helps clarify this particular issue.

As Eric Bentley pointed out, Thomas Carlyle's heroes inherit and embody the vital force once encouraged by the Byronic hero (Bentley 42). According to Bentley, Carlyle's theory on heroism evolves from, on the one hand, Lord Byron's prototype, and on the other, the philosophy of German thinker Johann Gottfried Herder: "For if a new picture of the individual and a new view of good and evil [Byron] are essential to Carlyle's philosophy, so is the new historical and evolutionary appetite [Herder]" (Bentley 42). In stating this, Bentley highlights the key points of Carlyle's discourse: first, Carlyle attempts to explain the enduring essence of heroism; and second, Carlyle tries to show how the concept of heroism is preserved through the unassailable flux of history. So, according to Carlyle, there is a common immanent trait that characterizes heroes as such, but the factual identities these heroes eventually acquire depend not so much on that trait, as on the historical context the hero lives in (LaValley 250). Therefore, Carlyle posits that there is a straightforward evolution in the outward form the hero adopts (Divinity, Prophet, Poet, Man of Letters, King). And this, in turn, implies that only through the history of "great men" (Carlyle 48), individuals get to know the history of the world:

The Great man is a Force of Nature: whatsoever is truly great in him springs-up from the inarticulate deeps $[\ldots]$. The hero is he who lives in the inward sphere of things, in the True, Divine and Eternal, which exists always, unseen to most, under the Temporary, Trivial: his being is in that; $[\ldots]$ His life, as we said before, is a piece of the everlasting heart of Nature herself. (Carlyle 112, 155)

Carlyle's stance is Neo-Platonic in nature. The essence of heroism depends on the robust bond linking an ideal substratum that Carlyle identifies with "the Divine" substance and human greatness, thus rejecting the "utilitarian fetish for mechanical structures" (Breton 52) that purportedly unfolds history from 
a materialistic point of view. These foundations are the blueprint and lie at the core of Victorian ideology (Auerbach 200).

All the way through On Heroes, Carlyle refers to the "Divine" substance in different ways: sometimes theologically - "Divinity", "Divine substance" (29, 45) - sometimes epistemologically - "Truth", "Only Truth" (40,43) - oftentimes both - i.e. "Divine Truth" (64). The basic outcome this formula (hero equals Divine Truth) triggers in the individual character of the hero operates in the realm of the will. Nevertheless, since the identity between hero and Truth is so inextricable, the hero cannot actually deny it without destabilizing his (her) own identity. Hence, the existing bond between heroism and Truth sets limits to the Hero's will, who then again feels compelled to a certain duty, that is, a duty to the Truth (Carlyle 125, 127). In view of this argument, it is no wonder that Carlyle quotes "sincerity" as the first unmistakable trait of the hero (125). Moreover, the need for sincerity beats the hero's fear of hiding the Truth - "a world drowned in fear cannot be a heroic world" (32). Thus, the first responsibility the hero must take is the duty of beating Fear: "Valour is still value. The first duty for a man is still that of subduing Fear. We must get rid of Fear; we cannot act at all till then. A man's acts are slavish, not true but specious; his very thoughts are false, he thinks too as a slave and coward, till he have got Fear under his feet" (Carlyle 32).

However, what does sincerity mean in this context? For Carlyle, it means the ability to detect the signs drawn by the Divine Truth. This idea becomes much easier to understand when considering Carlyle's critique of idolatry:

Idol is Eidolon, a thing seen, a symbol. It is not God, but a symbol of God; and perhaps one may question whether any the most benighted mortal ever took it for more than a Symbol. I fancy, he did not think that the poor image his own hands had made was God; but that God was emblemed by it, that God was in it some way or other. And now in this sense, one may ask, Is not all worship whatsoever a worship by Symbols, by eidola, or things seen? Whether seen, rendered visible as an image or picture to the bodily eye; or visible only to the inward eye, to the imagination, to the intellect: this makes a superficial, but no substantial difference. It is still a Thing Seen, significant of Godhead; and Idol. [...] All creeds, liturgies, religious forms, conceptions that fitly invest religious feelings, are in this sense, eidola, things seen. All worship whatsoever must proceed by Symbols, by Idols $[\ldots]$. Where, then, lies the evil of it? Condemnable Idolatry is insincere idolatry. (Carlyle 121) 
The previous explanation sheds light on the heroic trait that links, for instance, Mohammed (hero as prophet) with Martin Luther (hero as priest) - i.e., two notable instances of heroism in history, according to the Scottish philosopher. The supreme evil both figures fight against is nothing but false idolatry, a deceitful kind of worship that prevents individuals from getting in touch with the Divine Truth. However, while condemning this false kind of worship, Carlyle implies there is yet another kind of worship which stands out as the true type of worship. Since heroes are individuals who live in contact with the divine substance, is there a better way of getting in touch with that divine substance than worshipping an actual hero? The hero perceives it that way, and accordingly, feels the need to vindicate his (her) own figure. This process leads inevitably to the concept of "hero-worship", which represents the sincerest way of interacting with the world (Carlyle 11-15).

Hero-worship constitutes, ultimately, a form of faith and, as such, it exerts a powerful influence over the will of its followers: "Hero-worship, heartfelt prostrate admiration, submission, burning, boundless, for a noblest godlike Form of Man" (Carlyle 11). "Belief is great, life-giving" (77). While acknowledging the Truth in the hero, the hero worshipper (effectively, another kind of hero) aims his (her) belief at fulfilling sincere actions, namely, those which assure and sustain the heroic reality. Of course, in a present-day postcultural-materialist analysis this attitude implies a certain kind of ideology, for who establishes the nature of these sincere actions? Who indeed? Quite simply, the hero. The ideological mechanism hidden behind hero-worship is that individuals must subdue their will to the will of great men - again, "[h]eroworship, heartfelt prostrate admiration, submission, burning, boundless, for a noblest godlike Form of Man" (Carlyle 11) - hence generating a power system, or in other words, an ideological superstructure. Accordingly, since heroes hold responsibility towards the Truth and Divinity, and these manifest in all phenomena of life (including those which interfere in human interaction and society) then it is also the hero's duty to fulfil his (her) role as the guiding light of the community, hence faith - arguably the crucial element of Victorian ideology - and also loyalty, which implies duty and social responsibility (Bentley 53-60).

This theory coalesces in a political attitude that Eric Bentley labels as "Aristocratic radicalism" (20). These principles constitute the sincerest form of political structure in Carlyle's programme. If un-heroic individuals took over the very sovereignty heroes are bound to hold, then the political system would break at its root; it would literally become a maimed system, thus 
leading to a morbid political milieu. That is why Carlyle, here and there rejects, for instance, democratic-oriented movements of a republican drive (Breton 45). From the perspective of a hero worshipper, Carlyle condemns insincere political phenomena as the world's greatest malady (the term "malady" here being quite revealing of the seemingly "morbid" qualities these attitudes promote) (Carlyle 174). They are "republican in nature", indeed, for they somehow take the political unit of the individual citizen as chief structural tenet. Therefore, it stands to reason that a commitment to the individual, rather than to the communal welfare triggers in Carlyle a sense of sickness in society this explains, for instance, among other issues, Carlyle's condemnation of "idleness" (Breton 74). And still, however "morbid" these political systems may be, Carlyle also claims that they can be reversed properly in due time. The appearance of the hero in different political contexts is but a cyclical phenomenon, and it helps redirect the "morbid" situation until it becomes a sincere, say "healthy", political structure again. However, despite Carlyle's idea of History as a series of continuous, seemingly never-ending cycles of true heroism and false idolatry, the idealistic trait in his theory reveals a strong belief in a somewhat teleological progress. In Bentley's words: "Carlyle did believe in progress, however without much consistency", "progressive might be a more accurate description of [his] belief" (Bentley 46; emphasis added).

Admittedly, the core of the issue amounts to a matter of responsibility; most specifically to the type of responsibility that articulates power structures. On the one hand, if a political structure is based and reasserted along the axis of hero-worship (a commitment to the hero and the community he - and for Carlyle it is usually a he - preserves), that political structure will eventually unfold as True (and Divine). On the other hand, any political system that allows room for a commitment to the individual subject, rather than the hero, will come off as false, and thus, ostensibly morbid. This creates an interesting dialectical opposition between communal commitment - a responsibility devoted to the welfare of the community; a community, in turn, depicted as sincere, faithful, brave, progressive and socially committed "to work" (Breton 35) - and individual responsibility, which Carlyle perceives as morbid, thus creating a hermeneutical blueprint, a critical apparatus that measures the actual degree of cohesion communal structures boast.

This is where Conrad and Marlow (Heart of Darkness) step in. Let me probe further into the idea of individual commitment, or rather, individual responsibility, for this is the key to the morbid hermeneutics these pages engage with. 
The philosophical programme sitting at the core of late-nineteenth century ideas on individual responsibility might easily be the Nietzschean duality of the Dionysian substratum (BT 10) versus the Apollonian forces in consciousness, that is, the tragedy of individuation. Man cannot feel responsible for his actions insofar as he belongs to a realm of finite forces (i.e., Dionysian substratum) (Safranski 67) whose main dynamics, according to Nietzsche (Safranski 69) is already determined. By virtue of man's consciousness, the individual subject does not perceive the link between him and the Dionysian substratum (TL 246-247), thus creating illusions such as freedom, will or responsibility. However, there is a special kind of subject who perceives the situation differently. The "Titanic" individual - pending the term "overman" (Safranski 7o) - does feel a close link to the Dionysian substratum, but at the same time, acknowledges the fact that he is torn apart from that substratum by means of his consciousness $\left(B T_{54}\right)$. This is what Nietzsche refers to as the "tragedy of individuation" (BT 54$)$. When perceiving this tragedy, the Titanic individual feels compelled to expand his consciousness to become part of the Dionysian substratum (i.e., reality). In order to do so, the Titanic individual must love his fate (which is the time dimension of the Dionysian substratum) as something desirable. But then again,

Nietzsche also dealt with this antinomy of freedom explicitly and momentously in the context of his doctrine of recurrence, entreating us to love our destiny - amor fati. Loving necessarily means adding something to it, which alters it. When we embrace our fate, it evolves from something that was merely endured. We can therefore rest assured that the free spirit, which makes freedom vanish with its "evil laughter", is bound to conjure it up again in due course. (Safranski 177)

In doing so, the Titanic individual becomes responsible for his new creation. The amor fati theory arguably represents the biggest contradiction in Nietzsche's philosophy, but the author dodges it in quite a subtle way. According to the philosopher, amor fati reveals the true meaning of yet another capital issue in Nietzsche's programme: the will to power. The ultimate sense of the Will to Power (with relation to the amor fati theory) is that the Titanic individual actually desires to create and take control over his own identity by taking sole responsibility for his own destiny (amor fati), which, paradoxically, he cannot escape due to the deterministic nature of the Dionysian substratum. Ultimately, the delusion of responsibility is the way Man has developed in 
order to take over the fatum he nevertheless takes part in. Therefore, the Over-human character (the titanic individual) can be defined as the person who creates, dominates, and feels responsible for, his own world (Safranski 176-177). The concept of responsibility articulates the difference between the deterministic conception of Being in the nineteenth century (which largely started with Kant but found an update in the materialistic view of pragmatism and evolutionism) and the postmodern existentialist concept of Man's circumstance being the consequence of Man's own actions (Valls Oyarzun 31). In dealing with the idea of responsibility, Nietzsche somehow foresees the theories of such contemporary philosophers as the Italian Gianni Vattimo or German Rüdiger Safranski, who agree on describing responsibility as the performance of one's own will (will to power, that is) by virtue of which the subject eventually relates, alters and becomes the owner of his or her own reality.

In sum, according to Nietzsche, the basis of the modern, free individual subject lays on his sense of individual responsibility, as opposed to communal responsibility or the duty any subject might feel towards his or her own community (or society).

The Nietzschean reading of Heart of Darkness is not as far-fetched as it might seem at first. The works of Edward Saïd and, most notably, Professor Nic Panagopoulos (98-106) opened up the path for the $21^{\text {st }}$ century reader of Heart of Darkness to understand the novel both as a rendition and a challenge to the basic principles of Nietzschean thought. Heart of Darkness, for instance, comprises two critical issues in Nietzsche's philosophy: first of all, the idea of the Overman - which can easily be associated to Kurtz (Panagopoulos 98-100; Valls Oyarzun 223-242) - and secondly, the concept of the jungle as a symbol of the abysmal thought, that is the "titanic" rendition of life, i.e., the "Dionysian substratum" (BT 68) - traditional readings of Kurtz, for instance, deem the character a failure, insofar as he is incapable of "[withstanding] the temptations [inherent to playing] God" in the jungle (Hampson 110), thus finding an abyss within his own self: "In the great solitude of the jungle, Kurtz has found no source of restraint, either outside or inside himself. In the exercise of his power, he has opened himself to other forces within: 'the heavy muted spell of wilderness... seemed to draw him to its pitiless breasts by the awakening of forgotten and brutal instincts" (Hampson 111).

The character of Kurtz comprises most of the elements that define the Titanic Individual. Kurtz, has "seen [himself] seeing into the abyss" ( $z$ 177). His mates in the company, who resent Kurtz's hoarding of ivory, ostensibly denounce 
his will to power. Interestingly, Kurtz adds the concept of Eternal Recurrence to his main philosophical programme (Valls Oyarzun 223-241; Panagopoulos 98-100), since the impressionistic nature of Kurtz's narrative ("The horror, the horror!"), as rendered by Marlow, implies a certain conception of life as a force that keeps coming back: "Did he live his life again in every detail of desire, temptation, and surrender during that supreme moment of complete knowledge?" (Conrad 118) (cf. Valls Oyarzun 227; Panagopoulos 73-77). Kurtz's relationship with his African mistress in the novella reinforces too this idea, for she conceivably represents the perfect embodiment of Life as an abyss (Valls Oyarzun 259-272). Last but not least, Kurtz's "choice of nightmares" ultimately informs his commitment solely to himself, transcending previous engagements with society in the form of the "cause instructed by Europe" (Conrad 89). In other, words, Kurtz seems to embody the notion of individual responsibility to the letter, thus becoming a truly morbid character - no wonder he is coded as a "sick person".

Marlow, on the other hand is - at least at the beginning of the novella a Carlylean type of character. The ideological standpoint Marlow (in pre-Africa capacity) displays is the work ethic: "What saves us is efficiency - the devotion to efficiency" (Conrad 20). On the one hand, work is the civilizing tool par excellence, and on the other, all traits of human nature eventually acquire dignity through it: "Maintaining a classic work ethic against the corrupted organization and economic base of work is the responsibility of the individual in conflict with an individualist society" (Breton 101). Colonial activities, for instance, according to Marlow, become meaningless if they are not aimed at the effectiveness of production (Conrad 6o), hence Marlow's criticism of the Belgian control of Congo (Breton 101; Ophir 347). Work provides Humanity with a discipline, a plan of action, a series of rules that enhances the civilizing order (moderation, self-restraint) and somehow dims chaos in reality (Breton 101) - as long as it does not count humanity out, like in the Congo (Breton 101). A work ethic also informs social responsibility. Marlow sincerely commits to the civilizing value of work, to which he faithfully devotes himself as the ultimate Truth of the Victorian project. Indeed, he values people who are easy to work with, such as the character of the Helmsman, whilst despising those individuals who are impossible to trust due to their lack of efficiency (Hampson 111). A work ethic ultimately reveals a certain fondness for progress, for efficiency has to be accomplished somehow or other in an actual elevation of humanity.

Given this particular trait in the character, the pattern of the Carlylean 
archetype - thoroughly committed to the idea of progress and Truth revealing the falseness of the idolater, the morbid, individually responsible figure, becomes as apparent as it was for the late Victorian reader; and as problematic as it was then due to the hermeneutics of morbidity. Heart of Darkness problematizes the dialectic blueprint of Carlyle by dovetailing the hero's ideological hegemony with the morbid standpoint of the individualistic (say Nietzschean) character.

As the novella progresses, "[Marlow's] journey becomes a descent in search of meaning" (Hampson 108); the narrator probes into this meaning by delving in the character of Kurtz, eventually identifying with him. The process of recognition between Marlow and Kurtz (which in general terms constitutes a process of fulfilling the yearning for darkness) becomes more and more intense. Marlow's raw vision of the jungle - "the earliest", "atavistic", "beginnings of the world" (92), and his reading of Kurtz's report on the natives trigger a sort of fascination for the character that climaxes in the narrator's acceptance of his unassailable individual truth, so much so that the character actually embodies these truths in a sort of physical communion: "And I remember I confounded the beat of the drum with the beating of my heart, and was pleased at its calm regularity" (Conrad 105). Marlow's self then develops a sort of tellurian desire to merge with Earth, which is eventually (if partially) fulfilled in his meeting with Kurtz (Kurtz and the jungle being arguably one and the same thing) (Conrad 101).

What Kurtz (and indirectly, also Nietzsche) contributes to Marlow's character is the perception of what Michael Levenson calls "the groundlessness of values" (138), that is, the actual possibility of creating and developing new values from an individual standpoint of responsibility. Nietzsche's philosophical programme precludes that values would spawn from an ideal Truth or Divinity, but rather from the experience of a single character taking control over his individual will (let me add, "to power") (Ophir 348). According to Nietzsche, the origin of values resides in the different truth every perspective spawns; it sits at the core of every individual's consciousness. The "sight of the overman is an insight", it is an isolated sight, an extremely solipsist perception, arguably, the sight of an "idiot" (A 72). Marlow learns this the hard way, and vindicates the truth of it, inasmuch as he perceives Kurtz's valiant assertion of "the horror!" as a "moral victory" (Conrad 116). In view of this (new) Nietzschean, morbid reality, the only discourse he can articulate after coming back to the Victorian milieu is the "discourse" of an individual truth, based on perspective (which of course the Carlylean context perceives in turn as 
a lie, for reasons that will become apparent shortly). There is no more Truth, just perspectives, i.e., different and disparaging points of view, everlasting individual standpoints that redeem the subjective experience (Ophir 348) at the expense of communal, say Divine Truth. In Nietzsche's words:

Will they be new friends of 'truth', these coming philosophers? Very probably, for all philosophers hitherto have loved their truths. But assuredly they will not be dogmatists. It must be contrary to their pride, and also contrary to their taste, that their truth should still be truth for every one that which has hitherto been the secret wish and ultimate purpose of all dogmatic efforts. 'My opinion is my opinion: another person has not easily a right to it' - such a philosopher of the future will say, perhaps. ( $7 G B$ 245)

In Marlow's words:

'This simply because I had a notion it somehow would be of help to that Kurtz whom at the time I did not see - you understand. He was just a word for me. I did not see the man in the name any more than you do. Do you see him? Do you see the story? Do you see anything? It seems to me I am trying to tell you a dream - making a vain attempt, because no relation of a dream can convey the dream-sensation, that commingling of absurdity, surprise, and bewilderment in a tremor of struggling revolt, that notion of being captured by the incredible which is of the very essence of dreams...'

He was silent for a while.

'... No, it is impossible; it is impossible to convey the life-sensations of any given epoch of one's existence, - that which makes its truth. (Conrad 50)

Indeed, the singularity of Marlow's experience and the way he perceives it underwrite the impossibility of actually conveying such an experience, that is, the meaning of Marlow's (and Kurtz's) truth. The disintegration of the Truth, which can no longer be ascertained as a single, unique, fundamental and idealist reality, into a decadent strata of multiple layers of individual truth mirrors the corruption, i.e., the morbid status of commitment and responsibility Carlyle decried. Arguably though, Marlow does not adhere completely to the Nietzschean principle of individual responsibility. The lie he tells to Kurtz's Intended at the end of the novella ("The last word [Kurtz] 
pronounced was - your name") (120) constitutes a very good example of this. By lying to the Intended, Marlow positively acknowledges the Nietzschean reality Kurtz represents, but he effectively keeps it at bay, thus leaving the basic foundations of Victorian ethos (the Divine Truth) unscathed on the surface. In actual fact, Marlow's transformation seems incomplete, insofar as the narrator wittingly rejects the possibility of an overt Nietzschean victory over the Carlylean milieu; but then again, his unravelling of an "atavistic" abyss of darkness, by means of the narrative, adequately cancels basic Carlylean components such as faith in the possibilities of the Victorian project and sincerity (its survival depends on Marlow's lie, not on his upholding the Truth); in this context, consequently, social responsibility must fall apart too, for neither its final purpose (the Victorian project) or its dynamics (sincerity) comes off as incompatible with any notion of Divine Truth.

This is the desolate, morbid milieu the novella eventually achieves, "the heart of an immense darkness" (120). Both the structure of Heart of Darkness and Marlow's ideological standpoint (in pre-Africa capacity) resemble the Victorian narrative blueprint of the mid-century period, i.e., the Carlylean hero as denouncer of false idolaters. However, instead of achieving his task, here the Carlylean character unfolds the groundlessness of values that forcefully debunks classical Victorian conceptions of communal responsibility. Alternatively, the story reveals the Nietzschean principles of individual responsibility, which derive from individual characters embracing their fate (through "will to power") and accepting it unconditionally (amor fati). These principles comprise a solipsistic (albeit positive, as seen from Nietzsche's perspective) commitment of the individual to his or her own self, and point to individual responsibility as the fundamental ground of the modern subject. The hermeneutics of morbidity posited the dialectics of communal versus individual responsibility as a means to probe into the ideological traits at the core of any political superstructure. By wittingly accepting Kurtz's individual responsibility (akin to Nietzsche's principles) as a moral victory, Marlow subverts the idealistic tenets Carlyle upheld for his social programme, which was based on heroes and hero-worship. Conversely, in shying out of a complete Nietzschean victory, Marlow perpetuates the formal components of Carlyle's superstructure on the surface. These, nonetheless, have been depleted of ideological content and meaning, thus revealing a gloomy, apprehensive, yet unavoidable, design that can very well be labelled as - morbid. 


\section{Works Cited}

Auerbach, Nina. Woman and the Demon: The Life of a Victorian Myth. Cambridge: Harvard University Press, 1982. Print.

Bentley, Eric. The Cult of the Superman. London: Robert Hale, 1997 [1947]. Print.

Breton, Rob. Gospels and Grit: Work and Labour in Carlyle, Conrad and Orwell. Toronto: University of Toronto Press, 2005. Print.

Carlyle, Thomas. On Heroes, Hero-Worship, and the Heroic in History. Lincoln: University of Nebraska Press, 1966 [1841]. Print.

Conrad, Joseph. Lord fim. Ed. Robert Hampson and Cedric Watts. London: Penguin, 2000 [1900]. Print.

---. Heart of Darkness. Ed. Robert Hampson. London: Penguin, 1995 [1899]. Print.

Hampson, Robert. Foseph Conrad: Betrayal and Identity. London: Macmillan, 1992. Print.

Hillis Miller, J. Fiction and Repetition. Oxford: Blackwell, 1981. Print.

LaValley, Albert J. Carlyle and the Idea of the Modern. New Haven: Yale University Press, 1968. Print.

Levenson, Michael. Modernism and the Fate of Individuality. Cambridge: Cambridge University Press, 1991. Print.

Nietzsche, Friedrich. Beyond Good and Evil. Ed. and trans. Marion Faber. Oxford: Oxford University Press, 1998. [fGB]. Print.

---. Der Antichrist. Leipzig: Druck und Verlag, 1901. [A]. Print.

--. "On truth and lying in an extra-moral sense." Friedrich Nietzsche on Rhetoric and Language. Ed. and trans. Sander L. Gilman, Carole Blair and David J. Parent. Oxford: Oxford University Press. 246-257, 1989. [TL]. Print.

--. The Birth of Tragedy. Ed. Michael Tanner. Trans. Shaun Whiteside. New York: Penguin, 1993. [BT]. Print.

---. Thus Spoke Zarathustra. Ed. and trans. R. J. Hollingdale. New York: Penguin, 2003 [1961]. [Z]. Print.

Ophir, Ella. "Sincerity and Self-Revelation in Joseph Conrad." Modern Language Review. 107. October 2012: 341-363. Print.

Panagopoulos, Nic. The Fiction of Joseph Conrad: The Influence of Schopenhauer and Nietzsche. Bern: Peter Lang, 1998. Print.

Ruppel, Richard. A Political Genealogy of Joseph Conrad. London: Lexington, 2014. Print.

Safranski, Rüdiger. Nietzsche: A Philosophical Biography. Trans. Shelley Frisch. London: Granta Books, 2002. Print. 
Valls Oyarzun, Eduardo. Dueños del tiempo y del espanto: Genealogía nietzscheana de la responsabilidad en la narrative victoriana. Madrid: Escolar y Mayo, 2017. Print.

Watt, Ian. Conrad in the Nineteenth Century. New York: Macmillan, 1979. Print.

\section{Acknowledgement}

This paper was supported by the research project "Pensamiento y Representación Literaria y Artística Digital Ante la Crisis de Europa y el Mediterráneo", PR26/16-6B-2, Santander-Complutense. Coordinator (IP): Prof. Eduardo Valls Oyarzun.

EDUARDO VALLS OYARZUN is Associate Professor of Victorian Literature at the English Department, Complutense University, Madrid. His research interests range from ideology and the history of ideas in Nineteenth-Century Fiction, to Nietzsche's philosophy in Britain at the onset of Modernism. He has published and lectured extensively on Thomas Carlyle, Charles Dickens, Lewis Carroll, Oscar Wilde, Henry Rider Haggard, Robert Louis Stevenson, George Bernard Shaw and Joseph Conrad. His latest book is Dueños del tiempo $y$ del espanto ([Masters of Time and Horror $]$, Madrid, Escolar y Mayo, 2017), on the idea of responsibility in the Nineteenth Century.

evallsoyarzun@filol.ucm.es 